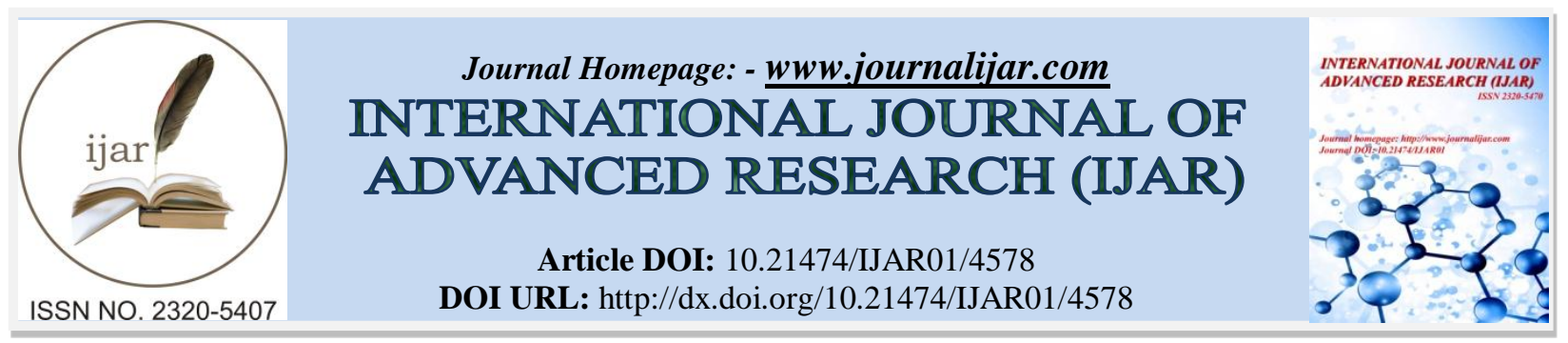

RESEARCH ARTICLE

\title{
MORPHOMETRIC ANALYSIS OF THE GAI RIVER BASIN, NE HIMALAYA, INDIA.
}

Sorat Konwar.

Department of Geology, Dimoria College, Khetri.

\section{Manuscript Info}

Manuscript History

Received: 23 April 2017

Final Accepted: 25 May 2017

Published: June 2017

Key words:-

Morphometric analysis, Gai River,

Geographic Information System (GIS)

\section{Abstract}

Morphometric analysis is refers as the quantitative evaluation of form characteristics of the earth surface and any landform unit. The quantitative analysis of the drainage morphometric system is vital to understand the hydrological and environmental interaction and its processes of an area. Geographical information system (GIS) has emerged as an efficient tool in delineation of drainage pattern and ground water potential and its planning. GIS and image processing techniques can be employed for the identification of morphological features and analysing properties of basin. In the present study Landsat -8 and Sentinal-2 image along with Cartosat DEM and Survey of India Toposheets are used. The Gai River basin is a sixth order basin, having 687 stream segments, encompassing an area of 148.30 $\mathrm{km}^{2}$ with a mean bifurcation ratio of 3.68 . The drainage density ranges from 0 stream per $\mathrm{km}$ to 5.99 streams per $\mathrm{km}$ with most of the high density area concentrating in the upper reach of the river, suggesting a lithological control coupled with climatic conditions. The average slope and the relative relief ranging between $0^{\circ}$ to $68.63^{\circ}$ per $\mathrm{km}$ and $8.04 \mathrm{~m} / \mathrm{km}^{2}$ to $506.26 \mathrm{~m} / \mathrm{km}^{2}$ respectively are directly controlled by the lithology of the basin as it shows higher value for hard rocks of Dafla Formation and lower values for non-compact conglomerate of Kimin Formation.

\section{Introduction:-}

Morphometry is the measurement and mathematical analysis of the configuration of the Earth's surface, shape and dimensions of its landforms (Clarke, 1966). This analysis can be achieved through measurement of linear, aerial and relief aspects of basin and slope contributions (Nag and Chakraborty, 2003). This is the most common technique in basin analysis, as morphometry form an ideal areal unit for interpretation and analysis of fluvially originated landforms where they exhibits and example of open systems of operation.

Morphology of a river system is shaped by the climate, lithology, structural fabric, neotectonic activity and vegetation of the area. The Gai River, a north bank tributary of the Brahmaputra River, which drains from the siwaliks of the Arunachal Himalaya in the north of Likhabali (94² $\left.41^{\prime} 27.6^{\prime \prime}: 27^{\circ} 39^{\prime} 18^{\prime \prime}\right)$, where it enters the Brahmaputra Plain of Assam is shaped by the underlying lithology, structure and the tectonic activity of the Himalayan orogeny along with climatic impact of high precipitation in the area. The river has a transverse relation with the general trend of structures of the Himalayan orogeny. Stream transverse to the structures of orogeny are 
commonly regarded as either antecedent to deformation or arbitrarily superimposed upon deformational structures from erosional surfaces covered by post orogenic sediments (T. M. Oberlander, 1985).

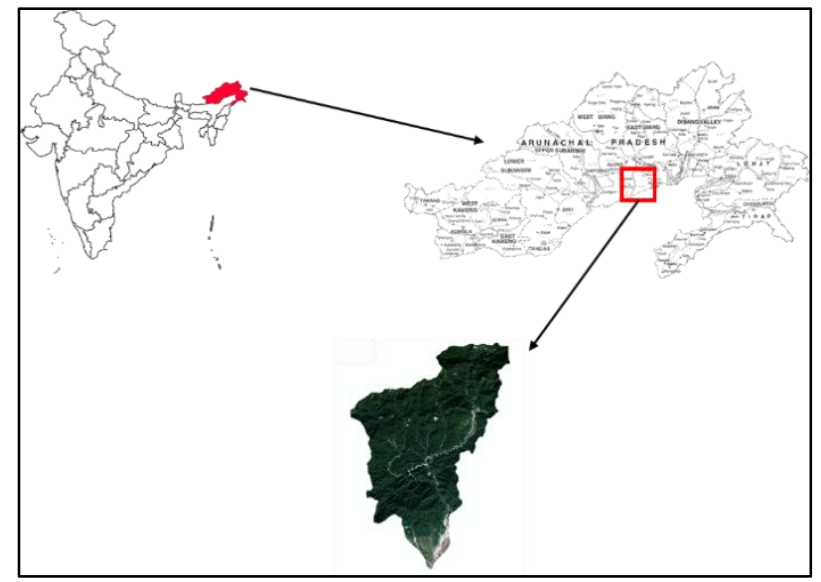

Fig 1:- Map of the study area

Geographical Information system (GIS) and Remote sensing techniques using satellite images are used as a convenient tool for Morphometric analysis. Many workers have carried out morphometric analysis using these new techniques. Digital Elevation Model (DEM) and Shuttle Radar Topography Mission (SRTM) widely used in drainage basin analysis.

\section{Geology:-}

Geologically the present study area comprises of Dafla Formation, Subansiri Formation and Kimin Formation of the Siwalik Group of tertiary age. The Dafla formation (equivalent to Lower Shiwalik) consists of alternating sandstone, shale and clay layers, which are hard as compared to overlaying Subansiri Formation (equivalent to Middle Shiwalik) and are less micaceous and quartzose, with its maximum thickness of about $3800 \mathrm{~m}$ thick to the north of Likhabali (Karunakaran and Ranga Rao, 1979; G. Kumar, 1997). The Subansiri Formation is a monotonous sequence of salt and pepper textured coarse to medium grained grey micaceous, soft, thick bedded massive sandstone. The Kimin Formation (equivalent to Upper Shiwalik) is dominantly a conglomeratic sequence consisting of alternating bands of conglomerate, soft sandstone and clays which is about $2300 \mathrm{~m}$ thick in Likhabali section (Karunakaran and Ranga Rao, 1979)

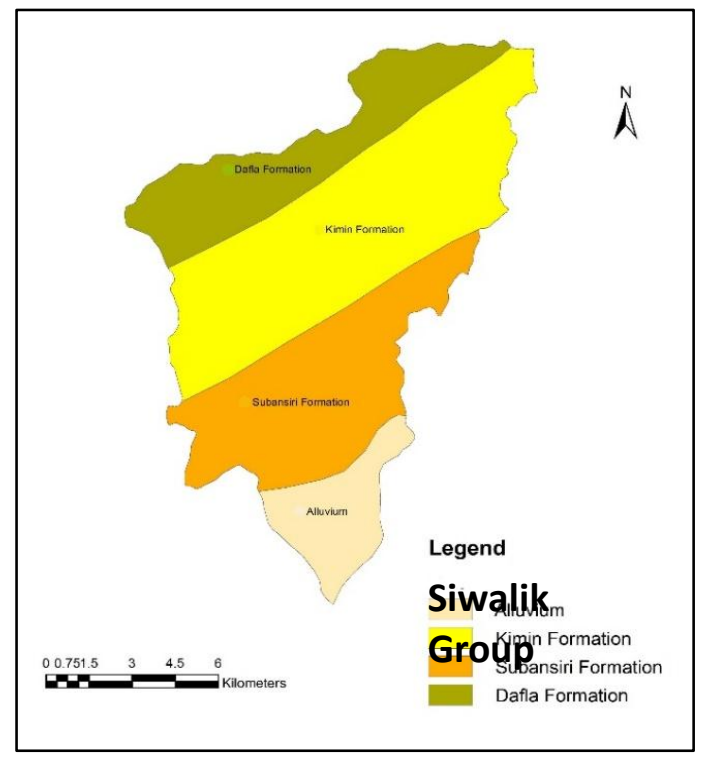

Fig 2:- Geological map of the area (after Gopendra Kumar, 1997) 


\section{Methodology:-}

In present study, morphometric analysis of Gai River basin is based on the integrated use of remote sensing and GIS technique. The Sentinel-2 satellite image and Survey of India (SOI) topographical maps: 83I/9 and 83I/10 at 1:50000 are geometrically rectified with respect to Landsat- 8 ortho-rectified image. The digitization of drainage pattern is carried out in Arc GIS software. For stream ordering, Strahler's law is followed by designating an unbranched stream as first order stream, when two first order streams join it is designated as second order. Two second order steams join together to form third order and so on. The number of streams of each order are counted and recorded. Morphometric parameters under linear, areal and relief aspect are computed using standard methods and formulae (Horton 1932, 1945; Strahler, 1964).The fundamental parameter namely; stream length, area, perimeter, number of streams and basin length are derived from drainage layer. The values of morphometric parameters namely; stream length, bifurcation ratio, form factor, elongation ratio and circularity ratio constant are calculated based on the formulae suggested by Horton (1945), Miller (1953), Schumm (1956), Strahler (1964). Drainage density map, average slope map and relative relief map have been prepared from Cartosat DEM in Arc GIS environment.

\section{Result and Discussion:-}

In the present study, the morphometric analysis for the parameters namely stream order, stream length, bifurcation ratio, basin length, drainage density, stream frequency, elongation ratio, circularity ratio, form factor, etc., has been carried out using standard mathematical formulae.

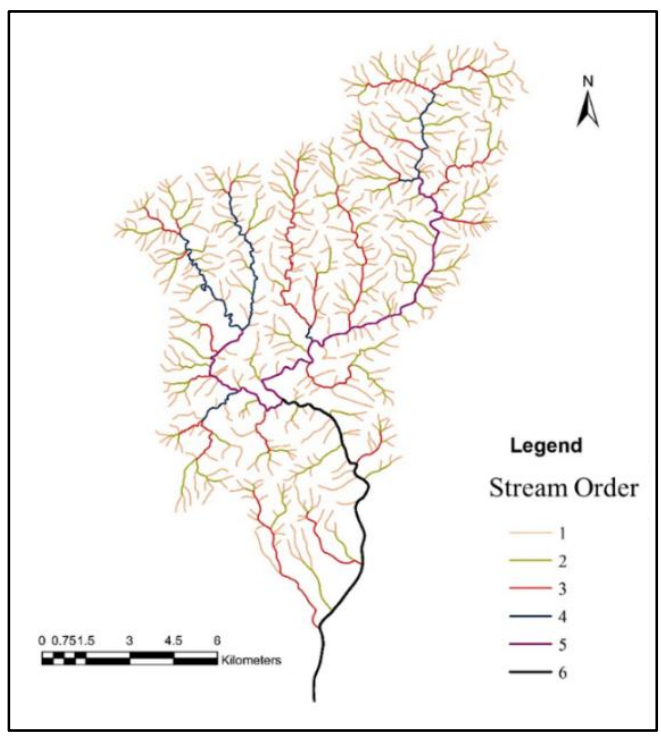

Stream order (u):-

Fig 3:- Gai drainage basin showing stream order.

A stream net or river net is the interrelated drainage pattern formed by a set of streams in a certain area. Ordering of the streams in the present study is done following Strahler's (1952) system. The head water that receive no tributary are first order streams. Two first order unite to give a second order stream and so on. The Gai River basin is a sixth order river basin.

Stream number $(\mathbf{N u})$ is the number of stream of the order $\mathbf{u}$.

Table 1:- Stream number $(\mathrm{Nu})$ for their respective stream order $(\mathrm{u})$.

\begin{tabular}{|c|c|}
\hline Stream Order $(\mathrm{u})$ & Stream Number $\left(\mathrm{N}_{\mathrm{u}}\right)$ \\
\hline 1 & 531 \\
\hline 2 & 121 \\
\hline 3 & 26 \\
\hline 4 & 6 \\
\hline 5 & 2 \\
\hline 6 & 1 \\
\hline
\end{tabular}




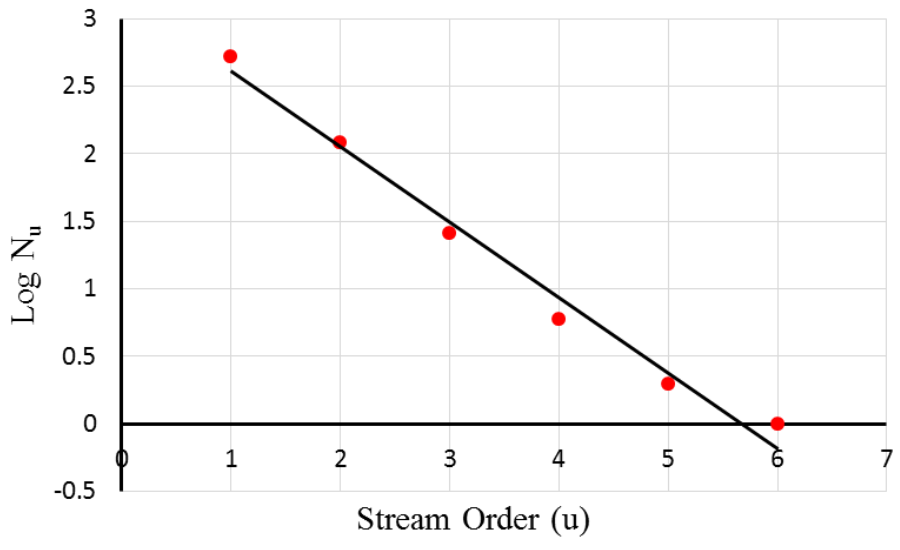

Fig 4:- Variation of $\log \mathrm{Nu}$ with stream order $(\mathrm{u})$

The stream number $(\mathrm{Nu})$ of the river basin decreases exponentially with the increase in stream order, which is in conformity with the Horton's Law of Stream Number (Horton, 1945), where if $\log \mathrm{N}_{\mathrm{u}}$ is plotted against $\mathrm{u}$ for any river net the data fall on a single straight line with $\mathrm{N}_{\mathrm{u}}$ decreases for increasing $\mathrm{u}$.

\section{Bifurcation ratio $\left(\mathbf{R}_{\mathrm{b}}\right)$ :-}

The term bifurcation ratio $(\mathrm{Rb})$ may be defined as the ratio of the number of the stream segments of given order to the number of segments of the next higher order (Schumn, 1956). Horton (1945) considered the bifurcation ratio as an index of relief and dissections. Strahler (1957) demonstrated that bifurcation ratio shows a small range of variation for different regions or for different environment except where the powerful geological control dominates. It is observed that, the $\mathrm{R}_{\mathrm{b}}$ is not same from one order to its next order. These irregularities are dependent upon the geological and lithological development of the drainage basin (Strahler, 1964).

Table 2:- Bifurcation ratio of the successive stream orders.

\begin{tabular}{|c|c|c|}
\hline Ratio (Stream order) & Bifurcation ratio $\left(\mathbf{R}_{\mathbf{b}}\right)$ & \multirow{2}{*}{ Mean Bifurcation ratio } \\
\hline $1 / 2$ & 4.39 \\
\hline $2 / 3$ & 4.65 \\
\hline $3 / 4$ & 4.33 \\
\hline $4 / 5$ & 3 \\
\hline $5 / 6$ & 2 & \\
\hline
\end{tabular}

Guisti and Schnider (1965) have shown that bifurcation ratio tend to decrease with increasing order. This trend is not observed in the present study as the $\mathrm{R}_{\mathrm{b}}$ value for higher order than $2 / 3$ trend to decrease. However, Singh et al., (1984) this hypothesis does not always hold good. The mean bifurcation ratio vary from 2.0 for flat or rolling basin to $3.0-4.0$ for mountainous, hilly dissected basins (Horton, 1945).the value of the present study area is in excellent agreement with the hilly dissected terrain, also observed in satellite imageries.

Stream Length $\left(\mathbf{L}_{\mathbf{u}}\right)$ :-

Stream length $\left(\mathrm{L}_{\mathrm{u}}\right)$ is the total length of streams of a given order $\mathrm{u}$ in a drainage basin and Mean stream Length $\left(\mathrm{L}_{\mathrm{sm}}\right)$ is average length in each order of the basin.

Table 3: Stream length $\left(\mathrm{L}_{\mathrm{u}}\right)$ and Mean Stream Length $\left(\mathrm{L}_{\mathrm{sm}}\right)$ in meters for their respective stream order

\begin{tabular}{|c|c|c|}
\hline stream order $(\mathbf{u})$ & stream length $\left(\mathbf{L}_{\mathbf{u}}\right)$ in meter & Mean stream length $\left(\mathbf{L}_{\mathbf{s m}}\right)$ in meter \\
\hline 1 & 269682.55 & 507.88 \\
\hline 2 & 76079.19 & 628.75 \\
\hline 3 & 53058.04 & 2040.69 \\
\hline 4 & 18592.81 & 3098.80 \\
\hline 5 & 19311.29 & 9655.65 \\
\hline 6 & 13000.35 & 13000.35 \\
\hline
\end{tabular}



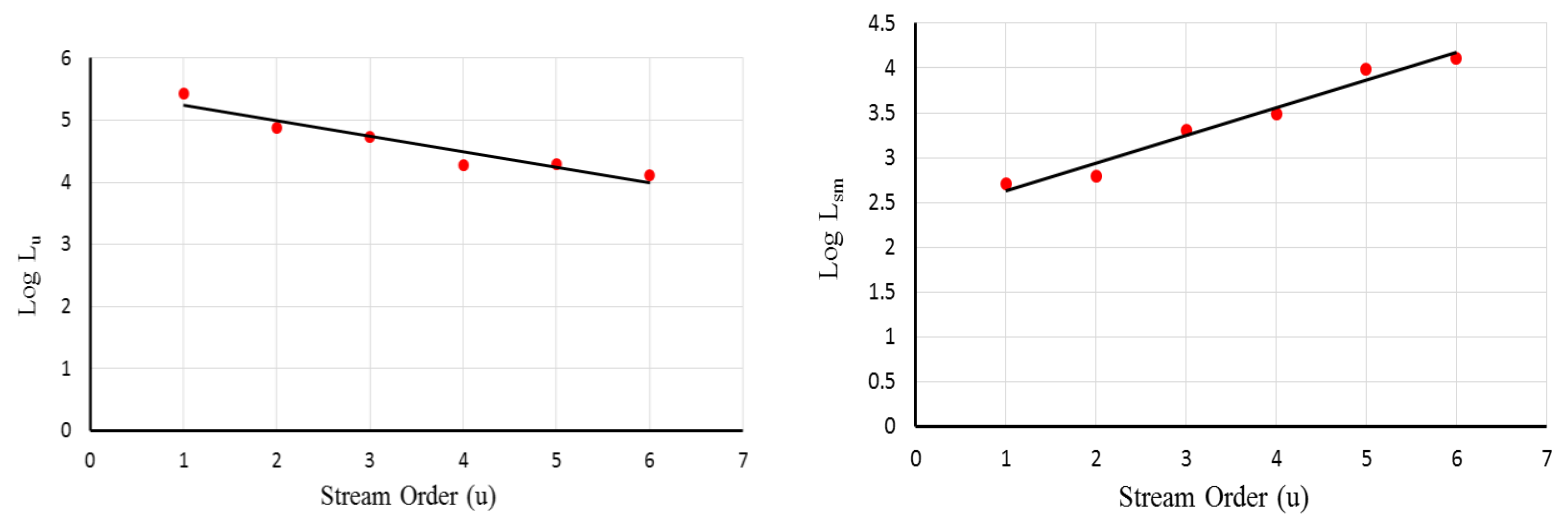

Fig 5:- variation of $\log \mathrm{L}_{\mathrm{u}}$ and $\log \mathrm{L}_{\mathrm{sm}}$ with stream order (u).

In the Gai River basin with the increase in stream order (u) the stream length $\left(\mathrm{L}_{\mathrm{u}}\right)$ decreases exponentially, whereas the mean stream length $\left(\mathrm{L}_{\mathrm{sm}}\right)$ exponentially increases, confirming Horton's Second Law of Stream Length, which states that, "the average lengths of the streams of each of different orders in a drainage basin tend closely to approximate a direct geometric series in which the first term is the average length of streams of first order" (Horton, 1945).

\section{Drainage density $\left(D_{d}\right)$}

Horton (1932) introduced drainage density (D) as an expression to indicate the closeness of spacing of channels. It is defined as the total length of streams of all orders per drainage area. Density factor is related to climate, type of rocks, relief, infiltration capacity, vegetation cover, surface roughness and run-off intensity index. This reflects a balance between erosive force and the resistance of ground, and, as a consequence, is closely related to climate and lithology (Summerfield, 2014). The present study area shows a drainage density ranging from 0 stream per $\mathrm{km}$ to 5.99 streams per $\mathrm{km}$. most of the high density area are concentrated in the upper reach of the river where the lithology are a Dafla Formation and Kimin Formation.

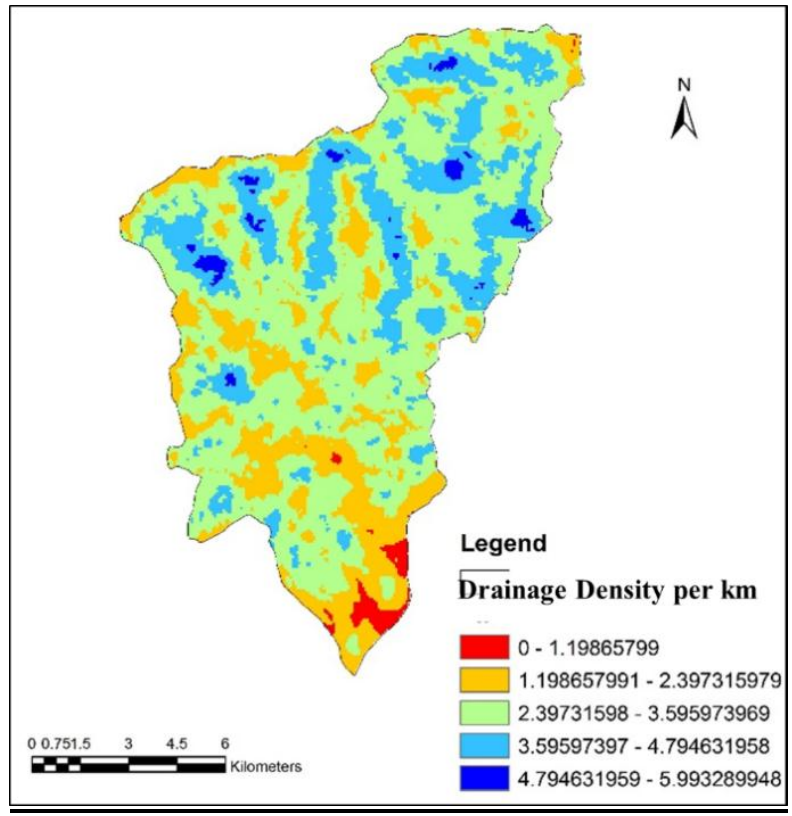

Fig 6:- Drainage density map of Gai River basin.

\section{Average Slope:-}

Slope is the inclination of a surface, measured in degrees from the horizontal surface. The average slope map (given below), reveals that the slope in the area ranges from a minimum of $0^{\circ}$ to a maximum of $68.63^{\circ}$. The average slope 
map gives a clear picture that slopes corresponding to the lithology of Dafla Formation and Subansiri Formation are steep, whereas it is gentle in Kimin Formation.

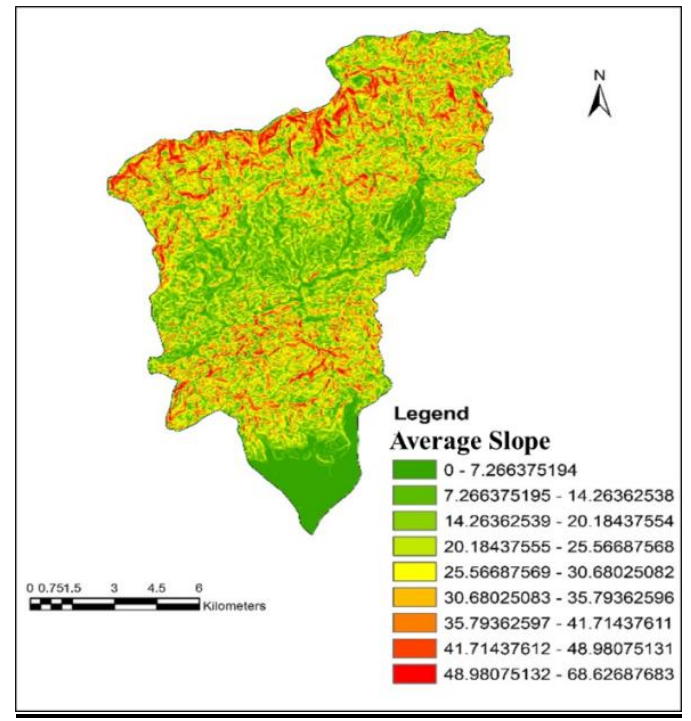

Fig 7:- Average Slope map of Gai River basin.

\section{Relative Relief:-}

Relative relief is the difference between the highest point and the lowest point in a unit area. It is use for an overall assessment of morphology of a terrain and its degree of desiccation. The relative relief I the present study area gives a value ranging from $8.04 \mathrm{~m} / \mathrm{km}^{2}$ to $506.26 \mathrm{~m} / \mathrm{km}^{2}$.

Highest relief in the region is shown by the area covered by Dafla Formation, whereas area covered by Kimin Formation shows lowest relief values with the exception of the alluvial cover. It is observed that the average slope and the relative relief have a conformable relation to each other.

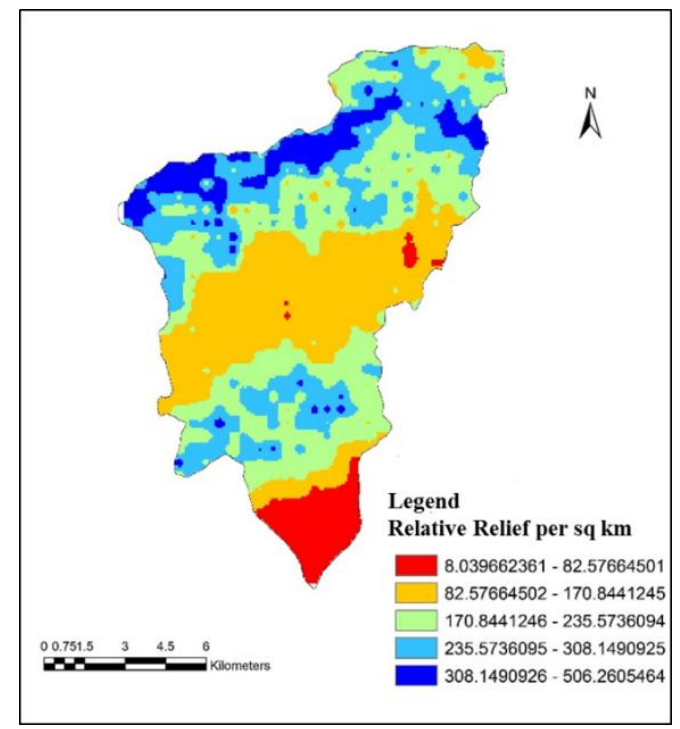

Fig 8:- Relative Relief map of Gai River basin.

The high value of the average slope and relative relief in the area covered by Dafla Formation is due to the absence of mica in the rocks and its hardness. In contrary the area covered by Kimin formation shows low values of average slope and relative relief as it is predominantly composed of conglomerates, which are less compact. 


\section{Basin Shape:-}

Basin shape affects the hydrologic characteristics of the basin, namely hydrograph. The Gai basin have an area of $148.30 \mathrm{~km}^{2}$, with a perimeter of $65.14 \mathrm{~km}$ and basin length of $21.37 \mathrm{~km}$. Parameters of basin shape such as from factor factor, circulatory ratio and elongation ratio are calculated for the basin

According to Horton (1932), form factor (Rf) may be defined, as the ratio of basin area to square of the basin length. Circulatory ratio $\left(\mathrm{R}_{\mathrm{c}}\right)$ is the ratio of the area of the basin to the area of a circle having the same circumference as the perimeter of the basin (Miller, 1953). Schumm (1956) defined elongation ratio (Re) as the ratio between the diameter of the circle of the same area as the drainage basin and the maximum length of the basin.

Table 4:- shape parameters of Gai River basin

\begin{tabular}{|c|c|}
\hline Parameter & Values \\
\hline Form factor $\left(\mathrm{R}_{\mathrm{f}}\right)$ & 0.32 \\
\hline Circulatory ratio $\left(\mathrm{R}_{\mathrm{c}}\right)$ & 0.44 \\
\hline Elongation ratio $\left(\mathrm{R}_{\mathrm{e}}\right)$ & 0.32 \\
\hline
\end{tabular}

Very low value of Rf, Rc and Re in Gai River basin suggest an elongated basin shape. The elongated shape of the basin is due to the high relief of the terrain and high erosion triggered by the recent tectonic activities in the area in assistance with high precipitation.

\section{Conclusion:-}

The Gai River having an area of $148.30 \mathrm{~km}^{2}$, drains from the Siwaliks of the Arunachal Himalaya having a transverse relation with the general structural trend of the orogeny. The river basin follows the laws of stream number and stream length proposed by Horton and his subsequent workers. The higher value of drainage density in the upper reach of the river and relatively lower value in the lower reach is due to the lithology of the basin, where in the upper reach is the Dafla Formation comprising of hard sandstone, shale and clay layers which are less micaceous and quartzous. The average slope and the relative relief of the basin has a direct conformable relation with the lithology as we have higher values for areas comprising of Dafla Formation and lower values for areas comprising of Kimin Formation.

\section{Reference:-}

1. Clarke, J.I., 1966. Morphometry from Maps. Essays in Geomorphology. Elsevier Publ. Co., New York, pp. 235-274.

2. Horton, R.E., 1932. Drainage Basin Characteristics. Trans. Am. Geophys. Union, 13: 350-361.

3. Horton, R.E., 1945. Erosional Development of Streams and their Drainage Basins; Hydrophysical Approach to Quantitative Morphology. Geol. Soc. Am. Bull., 56: 275-370.

4. Karunakaran, C., Ranga Rao, A., 1976. Status of exploration for the Hydrocarbons in the Himalayan regioncontributions to the stratigraphy and structure. International Himalayan Geological Seminar India. Section III, O.N.G.C, pp. 1-72.

5. Kumar, G., 2013. Geology of Arunachal pradesh. GSI.

6. Miller, V.C., 1953. A Quantitative Geomorphic Study of Drainage Basin Characteristics in the Clinch Mountain area, Virginia and Tennessee, Proj. NR 389-402, Tech Rep 3, Columbia University, Department of Geology, ONR, New York.

7. Nag, S.K. and Chakraborty, S., 2003. Influence of Rock Types and Structures in the Development of Drainage Network in Hard Rock Area. J. Indian Soc. Remote Sensing, 31(1): 25-35.

8. Oberlander,T.M.(1985) Origin of drainage transverse to structures in orogens. In:Tectonic Geomorphology (Ed. by M. Morisawas \& J.T. Hack), pp.155^182. Allen \& Unwin, Boston.

9. Schumm, S.A., 1956. Evolution of Drainage Systems and Slopes in Badlands at Perth Amboy, New Jersey. Geol. Soc. Am. Bull., 67: 597-646.

10. Strahler, A.N., 1952. Hypsometric (area-altitude) analysis of erosional topography. Geological Society of America Bulletin, 63(11), pp.1117-1142.

11. Strahler, A.N., 1957. Quantitative analysis of watershed geomorphology. Trans. Am. Geophys. Union, 38: 913-920.

12. Strahler, A.N., 1964. Quantitative geomorphology of drainage basins and channel networks. In: V. T. Chow (ed), Handbook of Applied Hydrology. McGraw Hill Book Company, New York, section 4-1I.

13. Summerfield, M.A., 2014. Global geomorphology. Routledge. 